Original Research Paper

\title{
Modeling and Forecasting of International Tourism Demand in ASEAN Countries
}

\author{
${ }^{1}$ Asrin Karimi, ${ }^{2}$ Pouya Faroughi and ${ }^{3}$ Khalid Abdul Rahim \\ ${ }^{1,3}$ Faculty of Economics and Management, University Putra Malaysia, 43400 UPM, Serdang, Selangor, Malaysia \\ ${ }^{2}$ Department of Statistics, Sanandaj Branch, Islamic Azad University, Sanandaj, Iran
}

Article history

Received: 17-06-2015

Revised: 26-07-2015

Accepted: 01-08-2015

Corresponding Author:

Asrin Karimi

Faculty of Economics and

Management, University Putra

Malaysia, 43400 UPM,

Serdang, Selangor, Malaysia

Tel: +601123741507

Email: asrin.karimi@gmail.com

\section{Introduction}

Today, tourism industry plays a key role in economic growth. The World Travel and Tourism Council (WTTC) estimated that tourism industry generated $10 \%$ of global GDP and 277 million jobs (1 in 11 job opportunity) in 2014.

Considerable number of literatures has been published on the relationship between tourism and economic growth. Surveys have shown that there was a positive and strong relationship between tourism and economic growth (Cortes-Jimenez and Pulina, 2010; Adnan Hye and Ali Khan, 2013; Tang and Abosedra, 2014; Pablo-Romero and Molina, 2013; Al-Mulali et al., 2014; Bouzahzah and El Menyari, 2013; Jalil et al., 2013). Sgroi et al. (2014) shown that rural communities improve economic growth. Tudisca et al. (2014) mentioned sustainable industries such as tourism industry increase economic growth.

ASEAN tourism ministers reported that this region received 99.2 million tourists in 2013. It shows an increase of $11.73 \%$ from 2012. Figure 1 shows that there is a clear increasing trend of international tourism arrival for a set of ASEAN countries during the period from 1995 to 2013 (World Bank).

Previous studies pointed out that tourism industry will be one of the three major industries which have direct effect on the world economy into the next century (Naisbitt, 1994).

In general, therefore it seems that an accurate estimation of international tourism demand has important economic consequences for the relevant industries, policy makers and governments in destination countries to implement long-term polices and plans to reduce the risk of failure or increase the possibility of achieving desired goals.

In recent years, there has been a growing interest in analyzing and forecasting tourism demand (Zhou-Grundy and Turner, 2014; Witt and Witt, 1995; Song and Li, 2008; Claveria and Torra, 2014; Peng et al., 2014). Researchers have used different quantitative methods for forecasting tourism demand. Extrapolative or time series methods are one of the common and useful methods which numerous studies have used. These methods consider historical patterns in a data series to forecast future values. They do not cover casual relationships (Frechtling, 1996). Previous studies utilized different extrapolative methods in modeling and forecasting demand in tourism.

Chan et al. (1999) considers Gulf War as an example and he found that Naïve is the best model for forecasting unstable data. Witt et al. (1994) compared annual data and seasonal data for forecasting and modeling international tourism demand. In this study, Naïve method was used. SES model (Chen et al., 2008; Witt et al., 1994), SMA model (Makridakis et al., 1998; Hu et al., 2004; Lim and McAleer, 2008), Box-Jenkins model (Makridakis and Hibon, 1979), ARIMA (Kim et al., 2011; Goh and Law, 2002; Preez and Witt, 2003), Holt's DES model (Lim and McAleer, 2001; Makridakis et al., 1998), BSM model (Greenidge, 2001; Gonzalez and Moral, 1995; Turner and Witt, 2001; Kulendran and Witt, 2003) are other time series methods used by scholars. 


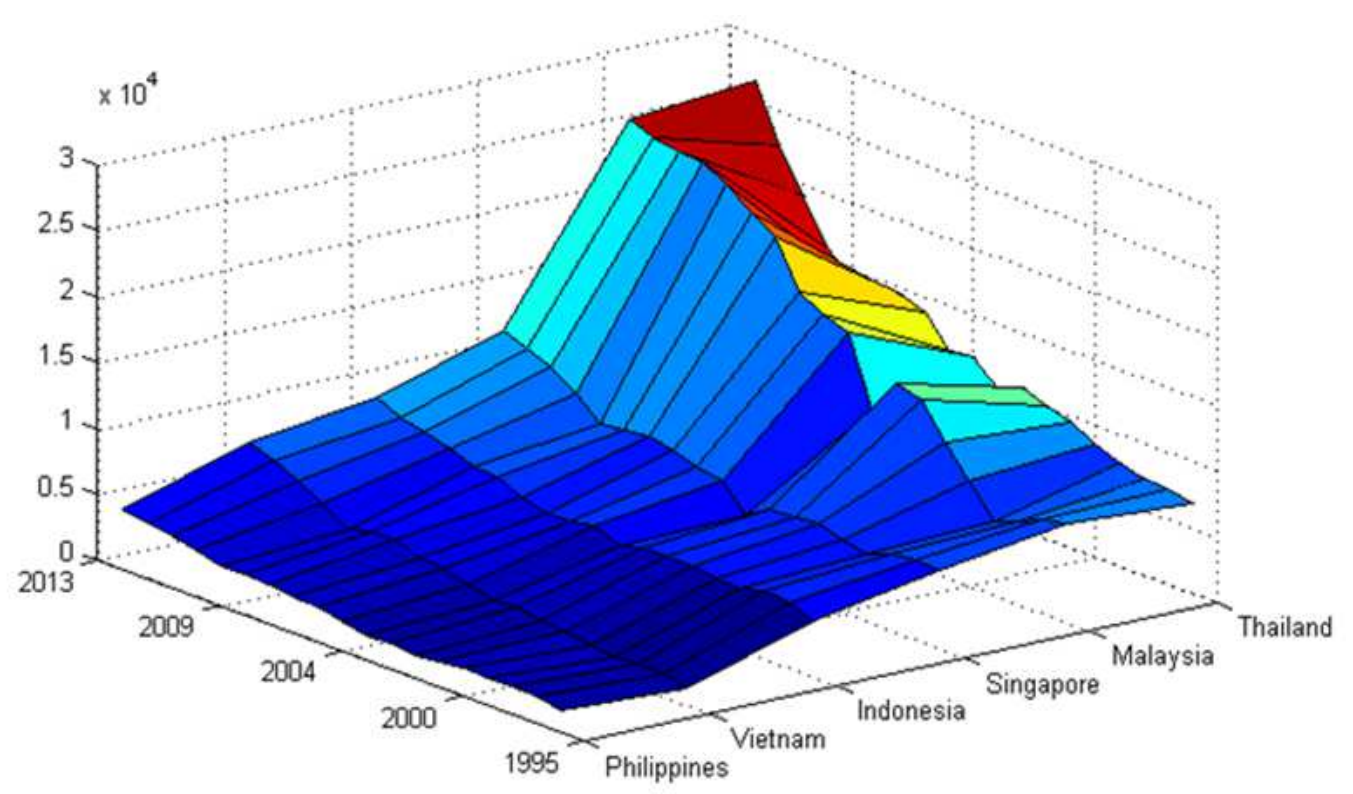

Fig. 1. Number of international tourist arrivals during the period time from 1995 to 2013 in six countries of ASEAN. Source: World Bank

Casual econometric methods are other quantitative forecasting methods. These methods are based on mathematical cause and effect relationships (Frechtling, 1996). These methods illustrate how explanatory variables affect the response variable (tourism demand) over time.

Vector Autoregressive (VAR), models are preferred to the single equation. Researchers used this model for long-run and short-run forecasting (Wong et al., 2006). $\mathrm{Hu}$ et al. (2004) provides the VAR models analysis to forecast international tourism demand in China for the period of 1978 to 1998. Time Varying Parameter (TVP) models consider structural instability and external shocks in tourism demand analyses (Song et al., 2000). Song et al. (2008) points out TVP model have better results in short-term forecasting. The TVP model has been used in different researches, such as (Witt et al., 2003; Li et al., 2004; Song et al., 2008; Song and Wong, 2003; Song et al., 1998).

The Error Correction Models (ECM) (Kulendran and Witt, 2001; Veloce, 2004; Ouerfelli, 2008; Song et al., 2008; Choyakh, 2008; Dritsakis, 2004; Halicioglu, 2010), The Dynamic AIDS model (Durbarry and Sinclair, 2003; Li et al., 2004; De Mello and Fortuna, 2005), Gravity Model (Che, 2004; Khadaroo and Seetanah, 2008; Guo, 2007) are other different casual econometric methods which are widely used in modeling and forecasting tourism demand researches.

This paper aims to fit a suitable model to predict international tourism demand using macroeconomic determinants by focusing exclusively on ASEAN countries. Most of previous studies focused on single macroeconomic determinant, microeconomic indicators, or from single country case studies. Unlike most of these studies, we consider the fundamental macroeconomic variables such as Foreign Direct Investment (FDI), exchange rate, inflation and openness of trade. Also, we adopt macroeconomic indicators within a panel data framework.

\section{Data}

In this study we evaluate various macroeconomic variables that might have a direct effect on the international tourist demand. Variables in our regression model include: (i) Foreign Direct Investment (net inflows) as a percentage of GDP (FDI), (ii) real exchange rate (EXCHN), (iii) inflation (INF) which is measured by the annual percentage change in the cost to an average consumer of acquiring a basket of goods and services and (iv) openness of trade (OPENS) which is measured by the sum of imports and exports over GDP.

The response variable in the regression model is the number of international tourist arrivals (TOUR). We measure the rate of tourist by the number of international tourism arrival. International incoming tourists are the number of tourists who travel to other countries outside their normal habitation.

ASEAN countries have been chosen for this study because of their importance on tourism destination in the world. The choice of the sample country and period depends on accessibility and availability of data on the variables. All of time series data are collected for the following countries: Indonesia, Malaysia, Philippine, 
Singapore, Thailand, Vietnam. This study covers the period of 1995-2013. The data are obtained from the World Development Indicator database which is published by the World Bank.

\section{Empirical Methodology and Results}

The first aim of this study is to investigate on the feature of the explanatory variables (FDI, real exchange rate, inflation openness of trade) and the response variable (international tourism arrival). The next purpose is to find the best model to estimate international tourism demand.

\section{Panel Unit Root Test}

Before conducting the panel data regression, we conducted a panel unit root test. For this purpose we adopt three different methods, namely those of the Im, Pesaran and Shin (IPS) test (Im et al., 2003), FisherADF and Fisher-PP statistics (Maddala and Wu, 1999; Choi et al., 1999). The null hypothesis of these tests is that each series in the panel is not stationary. Table 1 indicates our unit root test results. The results reveal that real exchange rate, inflation and openness of trade are not stationary at levels but they are stationary at the first difference (Table 2), therefore rejecting the null hypothesis indicate that the variables contain a panel unit root.

The results of panel unit root test indicate that time series are stationary at the first difference; thus, it seems that checking the cointegration of the series is necessary. In this study, the Pedroni panel cointegration test is employed. Pedroni (1999) was the first to develop heterogeneous panel cointegration test for series. This test allows us to accommodate individual specific fixed effects and definite trends and estimate coefficients for each series (Pedroni, 2004). In addition we use Kao residual cointegration test (Kao et al., 1999) to test the cointegration relationship in series.

Table 3 presents the panel cointegration test results. The Panel PP-statistic and Group PP-statistic strongly reject the hypothesis of no cointegration and Kao residual cointegration test also reject the hypothesis of no cointegration significantly at $5 \%$ critical value. Thus, there is a long-run relationship between the variables. This result shows that we can use the level of series for the Poisson regression model, GP and NBP regression model.

\section{Estimator Models}

Panel Poisson regression, negative binomial regression and generalized Poisson techniques are used in this study. These techniques have been widely used for count data (Greene, 2008). Individual effects are extended to two full distributional assumption, random effect assumption and fixed effect assumption (Hausman et al., 1984). The individual fixed effects model considers $\mathrm{N}$ countries which are relative to $\mathrm{T}$ (time series observation). Also, it is correlated with the independent variables (Wooldridge, 2010).

In this study individual fixed effects are chosen to estimate Poisson regression model because ASEAN countries are considered.

Table 1. Panel unit root test results

\begin{tabular}{lllllll}
\hline & $\begin{array}{l}\text { IPS } \\
\text { intercept }\end{array}$ & $\begin{array}{l}\text { IPS } \\
\text { intercept }+ \text { trend }\end{array}$ & $\begin{array}{l}\text { Fisher-ADF } \\
\text { intercept }\end{array}$ & $\begin{array}{l}\text { Fisher-ADF } \\
\text { intercept+ trend }\end{array}$ & $\begin{array}{l}\text { Fisher-PP } \\
\text { intercept }\end{array}$ & $\begin{array}{l}\text { Fisher-PP } \\
\text { intercept }+ \text { trend }\end{array}$ \\
\hline Tour & 7.943 & 4.429 & 0.173 & 4.542 & 0.115 & 4.244 \\
FDI & $-4.202^{* * *}$ & $-4.086^{* * *}$ & $39.871^{* * *}$ & $36.769^{* * *}$ & $36.676^{* * *}$ & $44.525^{* * *}$ \\
EXCHN & 1.98 & -0.813 & 5.111 & 17.114 & 4.314 & $19.210^{*}$ \\
INF & 0.385 & 0.385 & 0.845 & 10.629 & 0.464 & 9.973 \\
OPENS & 5.779 & 0.868 & 1.936 & 11.567 & 1.888 & 13.416 \\
\hline
\end{tabular}

Note: We used the Schwarz automatic selection of the lag length for the unit root test. The IPS, Fisher-ADF and Fisher-PP examine the null hypothesis of non-stationary. Probabilities for Fisher-type tests were computed by using an asymptotic $x^{2}$ distribution. All other tests assume asymptotic normality.

*Indicates that statistics are significant at the $10 \%$ level of significance.

$* * *$ Indicates that statistics are significant at the $1 \%$ level of significance.

Table 2. First difference panel unite root test results

\begin{tabular}{llllll}
\hline & $\begin{array}{l}\text { FD-IPS } \\
\text { intercept }\end{array}$ & $\begin{array}{l}\text { FD-IPS } \\
\text { intercept+ trend }\end{array}$ & $\begin{array}{l}\text { FD-Fisher-ADF } \\
\text { intercept }\end{array}$ & $\begin{array}{l}\text { FD-Fisher-ADF } \\
\text { intercept+ trend }\end{array}$ & $\begin{array}{l}\text { FD-Fisher-PP } \\
\text { intercept }\end{array}$ \\
\hline Tour & $-4.355 * * *$ & $-5.331 * * *$ & $40.735 * * *$ & $49.205 * * *$ & $42.306 * * *$ \\
FDI & $-9.010 * * *$ & $-7.084 * * *$ & $87.495 * * *$ & $60.544 * * *$ & $70.343 * * *$ \\
EXCHN & $-4.110 * * *$ & $-1.500 * * *$ & $37.856 * * *$ & $31.393 * * *$ & $180.490 * * *$ \\
INF & $-7.520 * * *$ & $-6.957 * * *$ & $67.875 * * *$ & $59.653 * * *$ & $36.478 * * *$ \\
OPENS & $-6.829 * * *$ & $-6.600 * * *$ & $62.564 * * *$ & $56.548 * * *$ & $101.725 * * *$ \\
\hline
\end{tabular}

Note: FD denotes first difference. $* * *$ indicates statisticalsignificanceatthe1\%. We used the Schwarz automatic selection of the lag length for the unit root test. The IPS, Fisher-ADF and Fisher-PP examine the null hypothesis of non-stationary. Probabilities for Fisher-type tests were computed by using an asymptotic $x^{2}$ distribution. All other tests assume asymptotic normality 
Table 3. Panel co-integration test results

\begin{tabular}{lllllllll}
\hline & Panel v & Panel rho & Panel PP & Panel ADF & Group rho & Group PP & Group ADF & Kao test \\
\hline Individual intercept & $2.546^{* *}$ & $-1.031^{* *}$ & $-3.914^{* * *}$ & $-3.925^{* * *}$ & 0.681 & $-3.536^{* * *}$ & $-3.290^{* * *}$ & \\
Deterministic intercept and trend & $2.170^{*}$ & 0.811 & $-1.326^{* * *}$ & $-1.258^{*}$ & 2.34 & $-2.337^{* * *}$ & -0.781 & $1.735^{* *}$ \\
\hline
\end{tabular}

Note: Statistics are asymptotically distributed as normal. ${ }^{* * *},{ }^{* *}$ and $*$ rejects the null of no co-integration at the 1,5 and $10 \%$ level, respectively. For the formulas used in the panel co-integration test statistics, it is described in details in Pedroni $(1999 ; 2004)$ and Kao et al. (1999).

* Indicates that statistics are significant at the $10 \%$ level of significance.

** Indicates that statistics are significant at the $5 \%$ level of significance.

*** Indicates that statistics are significant at the $1 \%$ level of significance

The panel Poisson regression model with fixed effects can be used as follows:

$$
\operatorname{Pr}\left(Y_{I}=y_{i}\right)=\frac{\exp \left(-\lambda_{i}\right) \lambda_{i}^{y_{i}}}{y_{i} !}, y_{i}=0,1,2, \ldots
$$

Let $Y=\left(Y_{1}, Y_{2}, Y_{3}, \ldots, Y_{n}\right)^{T}$ (be the response vector where $n$ is the sample size and $Y_{i}, Y_{j}$ are independent for any $\mathrm{i} \neq j$. If $Y_{i}$ is distributed as Poisson.

The covariates of $\lambda_{I}=E\left(Y_{i}\right)$ for Poisson regression model can be included using log link function:

$$
\log \lambda_{i}=x_{i t}^{T} \beta+\mu_{i}
$$

where, $x_{i}$ is the vector of covariates and $\beta$ is the vectors of regression parameters. With mean and variance, $E\left(Y_{i}\right)$ $=\operatorname{Var}\left(Y_{i}\right)=\lambda_{i}$. The term $\mu_{i}$ denotes individual effects.

The Poisson regression model has been widely used for modeling count data with covariates. In this model it is assumed that conditional mean and conditional variance functions are equal. This assumption limits the applications of Poisson regression model. Guloglu and Tekin (2012), stated that unobserved heterogeneity of cross-section units is causing overdispersion. Moreover, count data is often overdispersed and Negative Binomial (NB) regression has been used for handling overdispersion whereas Generalized Poisson (GP) regression has been fitted for under- or overdispersed count data.

A two-sided Likelihood Ratio Test (LRT) are performed to test the dispersion (over-or underdispersion) in panel Poisson regression against generalized Poisson or (negative binomial) alternatives (GP or NB) (Cameron and Trivedi, 1998) where the hypothesis is:

\section{$H_{0}:$ Dispersion Parameter $=0$ Against $H_{1}$ $H_{1}$ : Dispersion Parameter $\neq 0$}

Since Poisson model is nested within GP and NB models, the statistic is asymptotically distributed as a chi-square with one degree of freedom.

LRT statistic is:

$$
T=2\left(\ln L_{1}-\ln L_{0}\right)
$$

where, $\ln L_{1}$ and $\ln L_{0}$ are the models' log likelihood under their respective hypothesis.

The LRT for testing Poisson against GP regression models and Poisson against NB regression models are 364430.6 and 364412.6 respectively, indicating overdispersion in our data and reject null hypothesis of equality of mean and variance.

Several parameterizations were performed for the generalized Poisson and negative binomial regression models (Famoye et al., 2004; Wang and Famoye, 1997; Zamani and Ismail, 2012; Greene, 2008; Zamani et al., 2014). One of the parameterization of the GP regression model, which is used in this study, was used by Wang and Famoye (1997) for analyzing household fertility count data and by Ismail and Jemain (2007) for analyzing the Malaysian claim count data. In this study, negative binomial regression model form is used which is the most popular form. Greene (2008) used NB to panel data on health care utilization. The estimates of Poisson are suggested as initial values for fitting the GP and NB models. Table 4 shows the parameter estimates and t-ratio for the fitted models of the international tourism.

Comparison in terms of significance of estimates of covariates between Poisson, GP rand NB regression models shows that all models provide the same significant estimates at 0.10 level. All of the covariates except inflation under negative binomial regression model are significant at level 0.05 . The absolute values of $t$-ratio for dispersion parameter under GP and NB are 14.22 and 7.99 respectively, indicating that the dispersion parameter for both models is significant.

For a comparison of non-nested models, information criteria such as Akaike Information Criteria (AIC) and Bayesian Information Criteria (BIC) can be used. AIC and BIC are given by:

- $\quad \operatorname{AIC}=2 \operatorname{dim}(\theta)-2 \ln (\mathrm{L})$

- $\quad \mathrm{BIC}=\ln (\mathrm{n})-\operatorname{dim}(\theta)-2 \ln (\mathrm{L})$

where, $L$ is the maximum likelihood function for the estimated model.

The model with the smallest AIC or BIC is the best model. AIC includes a penalty by adding the number of parameters in the criteria, while BIC includes a penalty by adding the number of parameters and the sample size in the criteria. 
Table 4. Estimation results of Poisson, GP and NB regression model

\begin{tabular}{|c|c|c|c|c|c|c|}
\hline \multirow[b]{2}{*}{$\underline{\text { Parameter }}$} & \multicolumn{2}{|l|}{ Poisson } & \multicolumn{2}{|c|}{ Generalized Poisson } & \multicolumn{2}{|c|}{ Negative binomial } \\
\hline & est. & $|t|$ & est. & $|t|$ & est. & $|t|$ \\
\hline (TOUR, $Y$ ) intercept & $8.08 * * *$ & 2215.5 & $7.54 * * *$ & 36.3 & $7.83 * * *$ & 38.56 \\
\hline EXCHN & $-0.05 * * *$ & -189.2 & $-0.06 * * *$ & -3.65 & $-0.06 * * *$ & -4.14 \\
\hline FDI & $2.63 * * *$ & 259.5 & $2.71 * * *$ & 3.04 & $3.13 * * *$ & 4.74 \\
\hline INF & $-0.07 * * *$ & -43.1 & $-0.44 * * *$ & -4.01 & $-0.18^{*}$ & -1.73 \\
\hline OPENS & $0.13 * * *$ & 77.2 & $0.72 * * *$ & 4.48 & $0.27 * *$ & 2.28 \\
\hline Dispersion parameter & & & $0.01 * * *$ & 14.22 & $0.37 * * *$ & 7.99 \\
\hline Log likelihood & -183312.2 & -1096.9 & -1105.9 & & & \\
\hline AIC & 366634.4 & 2205.8 & 2223.9 & & & \\
\hline BIC & 366648.1 & & 2222.2 & & 2240.3 & \\
\hline
\end{tabular}

*Indicates that statistics are significant at the $10 \%$ level of significance.

**Indicates that statistics are significant at the $5 \%$ level of significance.

$* * *$ Indicates that statistics are significant at the $1 \%$ level of significance.

Based on the AIC and BIC in the Table 4 the GP regression model is the best model, followed by NB and Poisson regression models.

\section{Conclusion}

Table 4 illustrates the Poisson, GP and NB Poisson regression results. According to AIC and BIC results, GP regression model is the best model for forecasting international tourism demand. Based on our results inflation and real exchange rate has negative relationship with international tourism demand. Panel cointegration test result shows that there is a long- run relationship between variables.

In general, our findings fall in line with previous studies. The result shows that there is a positive significant relationship between FDI, openness of trade and international tourism demand. Numerous literatures have provided empirical evidence in support of these results. A number of studies have found that governments try to attract FDI for more international tourism arrival in developing countries (Andergassen and Candela, 2009). Siddique et al. (2012) illustrated that there is a causal interaction between FDI and tourism arrival. Also, an empirical study in China showed that there is a causal relationship between tourism arrivals, FDI and economic growth from 1978 to 2005 (Tang et al., 2007).

Numerous studies have attempted to explain the relationship between tourism and international trade. Previous studies explained that tourism industry met imports' needs and it enhance exports (Massidda and Mattana, 2012; Santana-Gallego et al., 2010). International tourism can make a lot of business opportunities by export sales and import purchases (Khan et al., 2005). Katircioglu (2009) found that there is a long-run relationship between international tourism arrival, economic growth, exports and imports in Cyprus. The author used ARDL-ECM model. Sarmidi and Saleh (2010) cross-country analysis (2009) showed a casual links between tourism and trade (export and import). Akinboade and Braimoh (2010) illustrated a causality links between real export and international tourism in long term.

Furthermore, the results indicate that there is a negative relationship between inflation, real exchange rate and international tourism demand. Chatziantoniou et al. (2013) pointed out there is reverse causality and negative effect between tourism industry and inflation.

Based on previous studies, exchange rate fluctuation plays a key role on tourism industry (Blake et al., 2008; Becken et al., 2008). Previous researches have reported that exchange rate has an adverse interaction with tourism arrival (Hanafiah and Harun, 2010). Other studies illustrated strong domestic currency has negative correlation on international tourism (Chang and McAleer, 2012). This study indicates that FDI, real exchange rate, inflation and openness of trade could be an effective tool, which can predict international tourism demand.

\section{Acknowledgement}

The authors would like to thank the reviewer for his effort and valuable comments.

\section{Author's Contributions}

Asrin Karimi: Was in charge of: (a) implementing the unite root test and the development co-integration test, (b) developed literature review.

Pouya Faroughi: Developed R program for fitting GP, NB regression and contributed to the writing of the manuscript.

Khalid Abdul Rahim: Contributed to the writing of the manuscript, designed the research plan and carried out the overall editing of manuscript.

\section{Ethics}

This article is original and contains unpublished materials. The corresponding author confirms that all 
of the other authors have read and approved the manuscript and no ethical issues involved.

\section{References}

Adnan Hye, Q.M. and R.E. Ali Khan, 2013. Tourismled growth hypothesis: A case study of Pakistan. Asia Pacific J. Tourism Res., 18: 303-313. DOI: $10.1080 / 10941665.2012 .658412$

Akinboade, O.A. and L.A. Braimoh, 2010. International tourism and economic development in South Africa: A Granger causality test. Int. J. Tourism Res., 12: 149-163. DOI: 10.1002/jtr.743

Al-Mulali, U., H.G. Fereidouni, J.Y. Lee and A.H. Mohammed, 2014. Estimating the tourism-led growth hypothesis: A case study of the Middle East countries. Anatolia, 25: 290-298. DOI: $10.1080 / 13032917.2013 .843467$

Andergassen, R. and G. Candela, 2009. LDCs, tourism investments and local economic development. University of Bologna.

Becken, S., A. Carboni, S. Vuletich and A. Schiff, 2008. Analysis of tourist consumption, expenditure and prices for key international visitor segments: Technical report. Lincoln University.

Blake, A., J.S. Arbache, M.T. Sinclair and V. Teles, 2008. Tourism and poverty relief. Ann. Tourism Res., 35: 107-126.

DOI: 10.1016/j.annals.2007.06.013

Bouzahzah, M. and Y. El Menyari, 2013. International tourism and economic growth: The case of Morocco and Tunisia. J. North Afr. Studies, 18: 592-607. DOI: 10.1080/13629387.2013.83632

Cameron, C.A. and P.K. Trivedi, 1998. Regression Analysis of Count Data (Econometric Society Monographs). 1st Edn., Cambridge University Press, ISBN-10: 0521632013, pp: 436.

Chan, Y., T. Hui and E. Yuen, 1999. Modeling the impact of sudden environmental changes on visitor arrival forecasts: The case of the gulf war. J. Travel Res., 37: 391-394 DOI: $10.1177 / 004728759903700409$

Chang, C. and M. McAleer, 2012. Aggregation, heterogeneous autoregression and volatility of daily international tourist arrivals and exchange rates. Japanese Economic Rev., 63: 397-419.

DOI: $10.1111 / \mathrm{j} .1468-5876.2011 .00563 . \mathrm{x}$

Chatziantoniou, I., G. Filis, B. Eeckels and A. Apostolakis, 2013. Oil prices, tourism income and economic growth: A structural VAR approach for European Mediterranean countries. Tourism Manage., 36: 331-341.

DOI: 10.1016/j.tourman.2012.10.012

Che, Y.B., 2004. An approach to modeling regional tourist attraction. Resource Develop. Market, 20: 163-165.
Chen, R.J.C., P. Bloomfield and F.W. Cubbage, 2008. Comparing forecasting models in tourism. J. Hosp. Tourism Res., 32: 3-21. DOI: $10.1177 / 1096348007309566$

Choi, W.M., A. Chan and J. Wu, 1999. A qualitative and quantitative assessment of Hong Kong's image as a tourist destination. Tourism Manage., 20: 361-365.

DOI: $10.1016 / \mathrm{S} 0261-5177(98) 00116-2$

Choyakh, H., 2008. A model of tourism demand for Tunisia: Inclusion of the tourism investment variable. Tourism Econom., 14: 819-838. DOI: $10.5367 / 000000008786440238$

Claveria, O. and S. Torra, 2014. Forecasting tourism demand to Catalonia: Neural networks vs. time series models. Economic Modell., 36: 220-228. DOI: 10.1016/j.econmod.2013.09.024

Cortes-Jimenez, I. and M. Pulina, 2010. Inbound tourism and long-run economic growth. Current Issues Tourism, 13: 61-74. DOI: $10.1080 / 13683500802684411$

De Mello, M.M. and N. Fortuna, 2005. Testing alternative dynamic systems for modelling tourism demand. Tourism Econom., 11: 517-537.509-521. DOI: $10.5367 / 0000005775108719$

Dritsakis, N., 2004. Cointegration analysis of German and British tourism demand for Greece. Tourism Manage., 25: 111-119. DOI: 10.1016/S0261-5177(03)00061-X

Durbarry, R. and M.T. Sinclair, 2003. Market shares analysis: The case of French tourism demand. Ann. Tourism Res., 30: 927-941. DOI: $10.1016 / \mathrm{S} 0160-7383(03) 00058-6$

Famoye, F., J.T. Wulu and K.P. Singh, 2004. On the generalized Poisson regression model with an application to accident data. J. Data Sci., 2: 287-295.

Frechtling, D.C., 1996. Practical Tourism Forecasting. 1st Edn., Butterworth-Heinemann, Oxford, ISBN-10: 0750608773, pp: 245.

Goh, C. and R. Law, 2002. Modeling and forecasting tourism demand for arrivals with stochastic nonstationary seasonality and intervention. Tourism Manage., 23: 499-510. DOI: $10.1016 /$ S0261-5177(02)00009-2

Gonzalez, P. and P. Moral, 1995. An analysis of the international tourism demand in Spain. Int. J. Forecast., 11: 233-251. DOI: $10.1016 / 0169-2070(94) 00570-3$

Greene, W.H., 2008. Econometric Analysis. 7th Edn., Granite Hill Publishers.

Greenidge, K., 2001. Forecasting tourism demand: An STM approach. Ann. Tourism Res., 28: 98-112. DOI: $10.1016 / \mathrm{S} 0160-7383(00) 00010-4$

Guloglu, B. and R.B. Tekin, 2012. A panel causality analysis of the relationship among research and development, innovation and economic growth in high-income OECD countries. Eurasian Economic Rev., 2: 32-47. DOI: 10.14208/BF03353831 
Guo, W., 2007. Inbound tourism, an empirical research based on gravity model of international trade. Tourism Tribune, 22: 30-34.

Halicioglu, F., 2010. An econometric analysis of the aggregate outbound tourism demand of Turkey. Tourism Econom., 16: 83-97. DOI: $10.5367 / 000000010790872196$

Hanafiah, M.H.M. and M.F.M. Harun, 2010. Tourism demand in Malaysia: A cross-sectional pool timeseries analysis. Int. J. Trade, Econom. Finance, 1: 80-83. DOI: 10.7763/IJTEF.2010.V1.15

Hausman, J.A., B.H. Hall and Z. Griliches, 1984. Econometric models for count data with an application to the patents-R\&D relationship. Econometrica, 52: 909-938. DOI: 10.3386/t0017

Hu, C., M. Chen and S.C. McChain, 2004. Forecasting in short-term planning and management for a casino buffet restaurant. J. Travel Tourism Market., 16: 79-98. DOI: 10.1300/J073v16n02 07

Im, K.S., M.H. Pesaran and Y. Shin, 2003. Testing for unit roots in heterogeneous panels. J. Econometr., 115: 53-74.

DOI: $10.1016 / \mathrm{S} 0304-4076(03) 00092-7$

Ismail, N. and A.A. Jemain, 2007. Handling overdispersion with negative binomial and generalized Poisson regression models. In: Casualty Actuarial Society Forum, the Society, pp: 103-158.

Jalil, A., T. Mahmood and M. Idrees, 2013. Tourismgrowth nexus in Pakistan: Evidence from ARDL bounds tests. Economic Modell., 35: 185-191. DOI: 10.1016/j.econmod.2013.06.034

Kao, C., M.H. Chiang and B. Chen, 1999. International R\&D spillovers: An application of estimation and inference in panel cointegration. Oxford Bulletin Econom. Statist., 61: 691-709. DOI: $10.1111 / 1468-0084.0610 \mathrm{~s} 1691$

Khadaroo, J. and B. Seetanah, 2008. The role of transport infrastructure in international tourism development: A gravity model approach. Tourism Manage., 29: 831-840.

DOI: $10.1016 /$ j.tourman.2007.09.005

Khan, H., R.S. Toh and L. Chua, 2005. Tourism and trade: Cointegration and granger causality tests. J. Travel Res., 44: 171-176. DOI: $10.1177 / 0047287505276607$

Katircioglu, S.T., 2009. Revisiting the tourism-ledgrowth hypothesis for Turkey using the bounds test and Johansen approach for cointegration. Tourism Manage., 30: 17-20. DOI: 10.1016/j.tourman.2008.04.004

Kim, J.H., K. Wong, G. Athanasopoulos and S. Liu, 2011. Beyond point forecasting: Evaluation of alternative prediction intervals for tourist arrivals. Int. J. Forecast., 27: 887-901.

DOI: $10.1016 /$ j.ijforecast.2010.02.014
Kulendran, N. and S.F. Witt, 2001. Cointegration versus least squares regression. Ann. Tourism Res., 28: 291-311.

DOI: $10.1016 / \mathrm{S} 0160-7383(00) 00031-1$

Kulendran, N. and S.F. Witt, 2003. Forecasting the demand for international business tourism. J. Travel Res., 41: 265-271. DOI: $10.1177 / 0047287502239034$

Li, G., H. Song and S.F. Witt, 2004. Modeling tourism demand: A dynamic linear AIDS approach. J. Travel Res., 43: 141-150. DOI: $10.1177 / 0047287504268235$

Lim, C. and M. McAleer, 2001. Forecasting tourist arrivals. Ann. Tourism Res., 28: 965-977. DOI: $10.1016 / \mathrm{S} 0160-7383(01) 00006-8$

Lim, C. and M. McAleer, 2008. Analysing seasonal changes in New Zealand's largest inbound market. Tourism Recreat. Res., 33: 83-91. DOI: $10.1080 / 02508281.2008 .11081292$

Maddala, G.S. and S. Wu, 1999. A comparative study of unit root tests with panel data and a new simple test. Oxford Bulletin Econom. Statist., 61: 631-652. DOI: 10.1111/1468-0084.0610s1631

Makridakis, S. and M. Hibon, 1979. Accuracy of forecasting: An empirical investigation. J. Royal Stati. Society A, 142: 97-145. DOI: $10.2307 / 2345077$

Makridakis, S., S.C. Wheelwright and R.J. Hyndman, 1998. Forecasting, methods and applications. 2nd Edn., Wiley, New York, ISBN-10: 047108610X, pp: 923.

Massidda, C. and P. Mattana, 2012. A SVECM analysis of the relationship between international tourism arrivals, GDP and trade in Italy. J. Travel Res., 52: 93-105. DOI: 10.1177/0047287512457262

Naisbitt, J., 1994. Global Paradox: The Bigger the World Economy, the More Powerful its Smallest Players. 1st Edn., W. Morrow, New York, ISBN-10: 0688127916, pp: 304.

Ouerfelli, C., 2008. Co-integration analysis of quarterly European tourism demand in Tunisia. Tourism Manage., 29: 127-137.

DOI: $10.1016 /$ j.tourman.2007.03.022

Pablo-Romero, M.D.P. and J.A. Molina, 2013. Tourism and economic growth: A review of empirical literature. Tourism Manage. Perspect., 8: 28-41. DOI: $10.1016 /$ j.tmp.2013.05.006

Pedroni, P., 1999. Critical values for cointegration tests in heterogeneous panels with multiple regressors. Oxford Bulletin Econom. Statist., 61: 653-670. DOI: 10.1111/1468-0084.0610s1653

Pedroni, P., 2004. Panel cointegration: Asymptotic and finite sample properties of pooled time series tests with an application to the PPP hypothesis. Econometric Theory, 20: 597-625. DOI: $10+10170$ S0266466604203073 
Peng, B., H. Song and G.I. Crouch, 2014. A metaanalysis of international tourism demand forecasting and implications for practice. Tourism Manage., 45: 181-193.

DOI: 10.1016/j.tourman.2014.04.005

Preez, J. and S.F. Witt, 2003. Univariate versus multivariate time series forecasting: An application to international tourism demand. Int. J. Forecast., 19: 435-451. DOI: $10.1016 / \mathrm{S} 0169-2070(02) 00057-2$

Santana-Gallego, M., F.J. Ledesma-Rodrيguez, J.V. Pérez-Rodrṣguez and I. Cortés-Jiménez, 2010. Does a common currency promote countries' growth via trade and tourism? World Economy, 33: 1811-1835.

DOI: $10.1111 / \mathrm{j} .1467-9701.2010 .01305 . x$

Sarmidi, T. and N.H. Salleh, 2010. Dynamic Interrelationship between Trade, economic growth and Tourism in Malaysia. Munich University Library.

Sgroi, F., A.M. Di Trapani, R. Testa and S. Tudisca, 2014. The rural tourism as development opportunity or farms. The case of direct sales in sicily. Am. J. Agric. Biol. Sci., 9: 407-419.

DOI: 10.3844/ajabssp.2014.407.419

Siddique, A., E.A. Selvanathan and S. Selvanathan, 2012. Remittances and economic growth: Empirical evidence from Bangladesh, India and Sri Lanka. J. Develop. Studies, 48: 1045-1062. DOI: 10.1080/00220388.2012.663904

Song, H. and G. Li, 2008. Tourism demand modelling and forecasting-A review of recent research. Tourism Manage., 29: 203-220.

DOI: 10.1016/j.tourman.2007.07.016

Song, H. and S.F. Witt, 2003. Tourism forecasting: The general-to-specific approach. J. Travel Res., 42: 65-74. DOI: $10.1177 / 0047287503253939$

Song, H., P. Romilly and X. Liu, 1998. The UK consumption function and structural instability: Improving forecasting performance using a timevarying parameter approach. Applied Econom., 30: 975-983. DOI: 10.1080/000368498325408

Song, H., P. Romilly and X. Liu, 2000. An empirical study of outbound tourism demand in the UK. Applied Econom., 32: 611-624. DOI: $10.1080 / 000368400322516$

Song, H., S.F. Witt and G. Li, 2008. The Advanced Econometrics of Tourism Demand. 1st Edn., Routledge, New York and London, ISBN-10: 1135852979, pp: 234.

Tang, C.F. and S. Abosedra, 2014. Small sample evidence on the tourism-led growth hypothesis in Lebanon. Current Issues Tourism, 17: 234-246. DOI: $10.1080 / 13683500.2012 .732044$
Tang, S., E.A. Selvanathan and S. Selvanathan, 2007. The relationship between foreign direct investment and tourism: Empirical evidence from China. Tourism Econom., 13: 25-39. DOI: $10.5367 / 000000007779784498$

Tudisca, S., A.M. Di Trapani, E. Donia, F. Sgroi and R. Testa, 2014. Entrepreneurial strategies of Etna wine farms. Int. J. Entrepreneurship Small Bus., 21: 155-164. DOI: $10.1504 / \mathrm{IJESB} .2014 .059470$

Turner, L.W. and S.F. Witt, 2001. Forecasting tourism using univariate and multivariate structural time series models. Tourism Econom., 7: 135-147. DOI: $10.5367 / 000000001101297775$

Veloce, W., 2004. Forecasting inbound Canadian tourism: An evaluation of error corrections model forecasts. Tourism Econom., 10: 262-280. DOI: $10.5367 / 0000000041895049$

Wang, W. and F. Famoye, 1997. Modeling household fertility decisions with generalized Poisson regression. J. Populat. Econom., 10: 273-283. DOI: $10.1007 / \mathrm{s} 001480050043$

Witt, C.A., S.F. Witt and N. Wilson, 1994. Forecasting international tourist flows. Ann. Tourism Res., 21: 612-628. DOI: 10.1016/0160-7383(94)90123-6

Witt, S.F. and C.A. Witt, 1995. Forecasting tourism demand: A review of empirical research. Int. J. Forecast., 11: 447-475. DOI: $10.1016 / 0169-2070(95) 00591-7$

Witt, S.F., H. Song and P. Louvieris, 2003. Statistical testing in forecasting model selection. J. Travel Res., 42: 151-158. DOI: $10.1177 / 0047287503253941$

Wong, K.K.F., H. Song and K.S. Chon, 2006. Bayesian models for tourism demand forecasting. Tourism Manage., 27: 773-780. DOI: 10.1016/j.tourman.2005.05.017

Wooldridge, J.M., 2010. Econometric Analysis of Cross Section and Panel Data. 1st Edn., MIT Press, ISBN-10: 0262232588, pp: 1064.

Zamani, H. and N. Ismail, 2012. Functional form for the generalized Poisson regression model. Commun. Statist. Theory Methods, 41: 3666-3675.

Zamani, H., N. Ismail and P. Faroughi, 2014. Poissonweighted exponential univariate version and regression model with applications. J. Math. Statist., 10: 148-154.

Zhou-Grundy, Y. and L.W. Turner, 2014. The challenge of regional tourism demand forecasting the case of China. J. Travel Res., 53: 6 747-759.

DOI: $10.1177 / 0047287513516197$ 